\title{
Insights into the immune responses of SARS-CoV-2 in relation to COVID-19 vaccines
}

\author{
Heedo Park ${ }^{\dagger}$, Mee Sook Park ${ }^{\dagger}$, Jong Hyeon Seok, \\ Jaehwan You, Jineui Kim, Jeonghun Kim, \\ and Man-Seong Park ${ }^{*}$ \\ Department of Microbiology, Institute for Viral Diseases, Chung Mong-Koo \\ Vaccine Innovation Center, College of Medicine, Korea University, Seoul \\ 02841, Republic of Korea \\ (Received Nov 16, 2021 / Revised Dec 24, 2021 / Accepted Dec 31, 2021)
}

The three types of approved coronavirus disease 2019 (COVID19) vaccines that have been emergency-use listed (EUL) by the World Health Organization are mRNA vaccines, adenovirus-vectored vaccines, and inactivated vaccines. Canonical vaccine developments usually take years or decades to be completed to commercialization; however, the EUL vaccines being used in the current situation comprise several COVID19 vaccine candidates applied in studies and clinical settings across the world. The extraordinary circumstances of the COVID-19 pandemic have necessitated the emergency authorization of these EUL vaccines, which have been rapidly developed. Although the benefits of the EUL vaccines outweigh their adverse effects, there have been reports of rare but fatal cases directly associated with COVID-19 vaccinations. Thus, a reassessment of the immunological rationale underlying EUL vaccines in relation to COVID-19 caused by SARSCOV-2 virus infection is now required. In this review, we discuss the manifestations of COVID-19, immunologically projected effects of EUL vaccines, reported immune responses, informed issues related to COVID-19 vaccination, and the potential strategies for future vaccine use against antigenic variants.

Keywords: COVID-19, SARS-CoV-2, immune response, mRNA-1273, BNT162b2, ChAdOx1 nCoV-19, Ad26.COV2.S, vaccine

\section{Introduction}

Coronavirus disease 2019 (COVID-19) was first observed in Wuhan, China in December 2019 as "pneumonia of un-

\footnotetext{
${ }^{\dagger}$ These authors contributed equally to this work.

${ }^{\star}$ For correspondence. E-mail: ms0392@korea.ac.kr

Copyright (C) 2022, The Microbiological Society of Korea
}

known cause" (https://www.who.int/emergencies/diseases/ novel-coronavirus-2019/interactive-timeline\# event-0; last accessed on November 9, 2021). Very quickly, a COVID-19 pandemic began that has so far claimed more than four million lives globally and included more than 200 million confirmed cases of infection (https://covid19.who.int/; last accessed on November 9,2021$)$. As the pandemic has progressed, COVID-19 has been shown to be a multifaceted disease involving more than "pneumonia." When the sequence of the virus causing COVID-19 became available, a race for vaccine development began. The speed and cooperative nature of the vaccine development process have been extraordinary; accordingly, the vaccine rollout began in December 2020 (Golob et al., 2021). However, since vaccine development occurred very rapidly, the complete characteristics of SARS-CoV-2 infection and COVID-19 manifestations have not been reflected in the development process; moreover, the appearance of virus variants has not been considered. Indeed, the vaccines have been developed based on the reference sequence of the first isolate submitted directly to NCBI on January 5, 2020 (https://www.ncbi.nlm.nih.gov/nuccore/NC 045512; last accessed on November 9, 2021) and subsequently published with phylogenetic characterizations (Wu et al., 2020); however, the virus infection characteristics have barely been revealed (Folegatti et al., 2020; Mulligan et al., 2020; Sadoff et al., 2021). Given the enormous effort of the developers, the vaccines approved by the United States Food and Drug Administration or World Health Organization (WHO) as emergency-use listed (EUL) vaccines appear to reduce the rate of fatality in countries in which a large proportion of the population has been vaccinated (https://covid19. who.int/region/amro/country/us; last accessed on November 9, 2021). Although several virus variants have appeared since the Wuhan strain (https://www.who.int/en/activities/trackingSARS-CoV-2-variants/; last accessed on November 9, 2021), few of the vaccines have lost their efficacy to the level of uselessness (Alrubayyi and Peppa, 2021; Tarke et al., 2021). Notably, vaccine shortages and vaccine avoidance have occurred together because infrequent but fatal adverse effects of the vaccines have been reported (Cines and Bussel, 2021). Thus, mitigating vaccine avoidance by providing a better understanding of the vaccine mechanisms may be as critical as mitigating vaccine shortages by scaling-up production.

Both mRNA vaccines and adenovirus-vectored vaccines have been under development for decades but have never been approved for use before this pandemic (Heinz and Stiasny, 2021). However, the pandemic became a stage on which these ex- 
perimental vaccine technologies could demonstrate their efficacy. In this review, we attempt to provide a better understanding of the workings of the EUL vaccines from an immunological perspective and we speculate on the causes of the manifested problems of these vaccines (Cines and Bussel, 2021; Kantarcioglu et al., 2021; MacNeil et al., 2021; Østergaard et al., 2021; Pottegård et al., 2021; Shay et al., 2021). We achieve this by reviewing the current knowledge of COVID-19, SARS-CoV-2 infection characteristics, immune responses to the infection, and immune mechanisms of the EUL COVID-19 vaccines.

\section{SARS-CoV-2 and COVID-19}

The COVID-19 causative virus was initially named 2019nCoV. Phylogenetically, the new coronavirus formed a clade within the subgenus Sarbecovirus of the genus Betacoronavirus from the subfamily Orthocoronavirinae of the family Coronaviridae ( $\mathrm{Lu}$ et al., 2020; Wu et al., 2020; Zhu et al., 2020). 2019-nCoV was recognized as forming a sister clade of SARS-CoV isolates in the phylogenetic relationship; thus, it was formally named SARS-CoV-2 by the Coronaviridae Study Group of the International Committee on Taxonomy of Viruses (Coronaviridae Study Group of the International Committee on Taxonomy of Viruses, 2020).

Coronaviruses have a positive-sense RNA genome that is $26-32 \mathrm{~kb}$ in size. The coronavirus genome functions as an mRNA and has a standard eukaryotic $5^{\prime}$-cap structure and a $3^{\prime}$ polyadenylate tail. The translated genome produces an RNA-dependent RNA polymerase protein and other proteins involved in viral replication. During replication, full-length genomic transcripts and several nested subgenomic transcripts are generated in membranous compartments of doublemembrane vesicles, i.e., away from the double-strand RNA detection conducted by the innate antiviral defense mechanism. Canonically, four major structural proteins of coronaviruses, namely the spike (S), membrane (M), and envelope (E) proteins in the viral membrane envelope and the nucleocapsid (N) protein in the ribonucleoprotein core, are translated from the individual subgenomic transcripts. The $M$ protein is the most abundant structural protein in coronaviruses. The transmembrane proteins of the E, M, and S are initially inserted into the endoplasmic reticulum (ER) and then transit to the ER-Golgi intermediate compartment (ERGIC) for assembly. In the ERGIC, the progeny viral genomes in complex with the $\mathrm{N}$ proteins coalesce with the envelope components and bud. The progeny virions are released from the infected cells by exocytosis. Coexpression of the $\mathrm{E}$ and $\mathrm{M}$ proteins is essential for the virus-like particle formation that is necessary for virion assembly. The S protein is gathered into the virion but is not required for virion assembly; it is an entry attachment and membrane fusion protein, and the membrane fusion function is activated by S1-S2 cleavage in the protein. A fraction of $S$ proteins not assembled into virions transit to the plasma membrane in some coronavirus infections, which results in syncytia formation around the infected cells. This overview is paraphrased excerpts from a virology textbook written by Masters and Perlman (2013).

Soon after the sequence of 2019-nCoV was released, com- parative analyses of the structural data from the $S$ protein of SARS-CoV and the S sequence of 2019-nCoV predicted the use of the host cell membrane protein, angiotensin converting enzyme 2 (ACE2), as an entry receptor, similar to that in SARS-CoV (Li et al., 2003; Wan et al., 2020a). It is well established that SARS-CoV-2 uses ACE2 as a receptor and that transmembrane protease serine subtype 2 (TMPRSS2) is the significant activating protease. It has a similar spectrum of cells as that of SARS-CoV (Hoffmann et al., 2020). However, SARS-CoV-2 binds to ACE2 better than SARS$\mathrm{CoV}$ can bind to this protein (Shang et al., 2020), which explains why SARS-CoV-2 has become more widespread than SARS-CoV and suggests that the appearance of variants better adapted for transmission among humans through interaction with ACE2 is to be anticipated (Tegally et al., 2021).

The type and location of ACE2- and TMPRSS2-expressing cells in the human body are critically associated with SARSCoV-2 transmission and COVID-19 pathology. ACE2 and TMPRSS2 expression sites relevant to transmission and pneumonia are related to nasal epithelial cells and pneumocytes in the lungs, respectively (Sungnak et al., 2020). However, ACE2 is abundantly expressed in endothelial cells and smooth muscle cells "in virtually all organs," although it is not expressed in immune cells (Hamming et al., 2004). SARS-CoV-2 can also infect cells that do not express TMPRSS2, which occurs through the endosomal pathway. The endosomal cysteine proteases cathepsin $\mathrm{B}$ and $\mathrm{L}$ can cleave the $\mathrm{S}$ protein to $S 1$ and S2 for the S protein activation required for fusion (Hoffmann et al., 2020). Although conflicting reports exist on ACE2 expression in endothelial cells (Hamming et al., 2004; Hoffmann et al., 2020), SARS-CoV-2 infection in endothelial cells has been reported (Varga et al., 2020; Wong et al., 2021). Vascular endothelial cell infection with SARS-CoV-2 appears to be important for COVID-19 manifestation beyond respiratory symptoms and pneumonia.

Clinical phenotyping of COVID-19 into three stages has been proposed by (Siddiqi and Mehra, 2020). Stage 1 is graded as "mild" with symptoms early in infection often involving nonspecific malaise, fever, and a dry cough. Patients with a viral infection limited to Stage 1 would likely recover well. Stage 2 is graded as "moderate" with pulmonary involvement; it leads to viral pneumonia accompanied by a cough, fever, and possibly hypoxia. At Stage 2, pulmonary disease is established along with viral multiplication and localized inflammation in the lungs. Stage 3 is graded as "severe" with extrapulmonary systemic hyperinflammation in which inflammatory cytokines and biomarkers are elevated and shock, vasoplegia, respiratory failure, cardiopulmonary collapse, and myocarditis might manifest in Stage 3. Moreover, this stage can end in multiorgan dysfunction.

From postmortem cases of COVID-19, a few signs of extrapulmonary infection were reported with thrombotic features in at least one major organ in all complete autopsies (Hanley et al., 2020). Plasma viremia of SARS-CoV-2 associated with severe disease represents a possible link to extrapulmonary multiorgan involvement (Li et al., 2021b). In severe COVID-19, cardiovascular complications, microvascular and macrovascular thrombosis, thromboembolism, and severe endothelial injury have been observed (Ackermann et al., 2020; Al-Samkari et al., 2020; Oxley et al., 2020; Varga 
et al., 2020; Bellmunt-Montoya et al., 2021). Vascular disease and thrombosis in COVID-19 have been shown to be recapitulated in SARS-CoV-2 infected rhesus macaques (Aid et al., 2020). COVID-19-associated endothelialitis resembles syndromes characterized by disruption of endothelial homeostasis and it results in dysregulation of coagulation, vascular tone, endothelial permeability, and vascular inflammation (Calabretta et al., 2021). COVID-19-associated coagulopathy also appears as an endotheliopathy from endothelial cell infection of SARS-CoV-2 (Goshua et al., 2020; O'Sullivan et al., 2020; Leentjens et al., 2021). The breadth and the extrapulmonary manifestations of COVID-19 due to endothelial cell infection are implied by other endothelial cell-infecting viruses such as hantaviruses (Sahni, 2007; Noack et al., 2020; Bae et al., 2021). For instance, the thromboembolic complications observed in COVID-19 patients have also been observed in hantavirus-infected cases (Connolly-Andersen et al., 2015; Schmedes et al., 2020). Although cases of blood donors later testing positive for COVID-19 have been reported, SARS-CoV-2 transmission from blood transfusion has not been reported (Leblanc et al., 2020). This suggests that endothelial cell infection does not likely occur during the asymptomatic phase, which is consistent with coagulopathy presumed to be due to endothelial cell infection associated with higher disease severity (Leentjens et al., 2021).

\section{Immune Responses against SARS-CoV-2}

Although there is an ongoing battle against the causative disease of COVID-19, immune responses against SARS-CoV2 have yet to be profiled sufficiently. In 2003, another type of coronavirus, namely SARS-CoV, emerged that infects the same types of cells as those infected by SARS-CoV-2. Thus, understanding SARS-CoV immunity could be an alternative solution to understanding SARS-CoV-2 immunity. Studies performed using SARS-recovered individuals after 12-23 months (Yang et al., 2007), at 6 years post-infection (Oh et al., 2011), and at 9-11 years post-infection (Ng et al., 2016) reported that SARS-CoV-specific memory $\mathrm{CD}_{4}^{+}$and $\mathrm{CD} 8^{+}$ $\mathrm{T}$ cells persisted for up to 11 years post-infection, where $\mathrm{CD}^{+} \mathrm{T}$ cells were prodominantly IFN $\gamma$-expressing $\mathrm{T}$ helper 1 (Th1) cells. To activate the most effective SARS-CoV-specific $\mathrm{CD}^{+} \mathrm{T}$-cell response and memory, an association with the SARS-CoV CD4 $4^{+}$T-cell response of Th1 activation in the first immune defense process would have been necessary (Medema et al., 2001; Ronchese and Hermans, 2001). Interestingly, anti-SARS-CoV IgG antibody titers have been shown to decline over time to a baseline from before five years postinfection; indeed, the SARS-CoV-specific B-cell memory response was not detectable at six years post-infection (Tang et al., 2011). It has also been shown that the T-cell responses of individuals who have recovered from SARS-CoV are highly cross-reactive to SARS-CoV-2 peptides and SARS-CoV-2 reactive $\mathrm{T}$ cells were found in people not exposed to SARS$\mathrm{CoV}-2$. This most likely arises due to previous infection with human "common cold" coronaviruses (Braun et al., 2020; Le Bert et al., 2020; Mateus et al., 2020).

One study suggested that preexisting SARS-CoV-2 crossreactive immunity from exposure to "common cold" corona- viruses affects the course of COVID-19 (Lipsitch et al., 2020). In another study, among the individuals who took PCR tests for endemic "common cold" coronaviruses $(\mathrm{eCoV})$ within the past five years before the start of the COVID-19 pandemic, $\mathrm{eCoV}^{+}$(positive) individuals had milder COVID-19 symptoms than those of $\mathrm{eCoV}^{-}$(negative) patients in terms of ICU admission, mechanical ventilation, and eventual death $\left(\mathrm{eCoV}^{+}\right.$ $4.8 \%$ versus $\mathrm{eCoV}^{-} 17.7 \%$ of the hospitalized patients) under a similar level of preexisting morbidity (Sagar et al., 2021). The preexisting cross-reactive immunity from eCoV infection appears to be insufficient to block SARS-CoV-2 infection but nevertheless supports the fight against the disease.

Determining relationships between disease severity and immune responses allows us to understand which types of immune response could be protective and which are pathologic. Autopsies of fatal cases of COVID-19 have revealed depletion of $\mathrm{CD}^{+} \mathrm{T}$ cells (Hanley et al., 2020). Interestingly, specific antibody responses in SARS-CoV-2 were shown to be more robust in patients with moderate/severe symptoms or those that were hospitalized compared with in patients exhibiting mild symptoms or those that were not hospitalized (Dan et al., 2021; Tan et al., 2021), and a higher level of nAb (neutralizing antibody) with higher disease severity was also observed with SARS-CoV infection (Li et al., 2008). Contrastingly, SARS-CoV-2-specific $\mathrm{CD}^{+}$and $\mathrm{CD}^{+} \mathrm{T}$-cell memory responses tended to be lower in hospitalized patients compared with in unhospitalized individuals (Dan et al., 2021). The presence of SARS-CoV-2-specific $\mathrm{CD} 4^{+}$and $\mathrm{CD}^{+} \mathrm{T}$ cell responses in the acute phase has been significantly associated with mild disease, whereas the presence of $n A b$ was not associated in this manner (Rydyznski Moderbacher et al., 2020). SARS-CoV-2-specific CD $4^{+} \mathrm{T}$ cells in the acute phase of COVID-19 primarily consist of follicular helper $\mathrm{T}$ cells and IFN $\gamma$-producing Th1 cells (O'Shea and Paul, 2010; Liao et al., 2013; Li et al., 2014); SARS-CoV-2-specific IFN $\gamma^{+}$ $\mathrm{CD}^{+} \mathrm{T}$ cells have been detected as early as four days postsymptom onset (PSO) and are predominantly granzyme-expressing cells (Rydyznski Moderbacher et al., 2020). A higher frequency of IFN $\gamma$-secreting cells was present in both the early (days 1-15 PSO) and late (days 15-30 PSO) stages of mild COVID-19 cases but not in moderate/severe cases (Tan et al., 2021). Notably, a fatal case was reported with nAb but without detectable SARS-CoV-2-specific $\mathrm{CD}^{+}$and $\mathrm{CD}^{+}$ $\mathrm{T}$-cell responses. In addition, a case was resolved without hospitalization and detectable nAb but with SARS-CoV-2specific $\mathrm{CD}^{+}$and $\mathrm{CD}^{+} \mathrm{T}$-cell responses (Rydyznski Moderbacher et al., 2020). All accounts suggest that the ability of $\mathrm{T}$ cell-mediated immunity to control infection in the acute phase is critically correlated with mild COVID-19 cases.

Serum antibody testing in patients that have fully recovered after a mild illness from SARS-CoV-2 infection have shown that most patients had confirmed COVID-19 seroconverted with IgG antibodies developing slowly over 7-50 days (median 24 days) PSO and 5-49 days (median 15 days) from symptom resolution; a positive antibody response to SARS-CoV-2 increased from $28 \%$ of patients within two weeks of symptom resolution to $94 \%$ within four weeks, and symptom duration was associated with higher antibody titers (Wajnberg et al., $2020 b$ ). Although robust nAb responses to SARS-CoV-2 infection stable for at least five months have been reported 
(Wajnberg et al., 2020a), the role played by nAb in symptom resolution has yet to be confirmed. A clinical trial involving the $\mathrm{nAb}$ cocktail REGN-COV2, which included 1,000fold titers relative to those achievable in convalescent plasma, showed a dramatic reduction in viral titers from baseline serum antibody-negative COVID-19 patients with a high baseline viral load at the beginning of the trial. However, the time required to alleviate symptoms was not strongly associated with treatment (Weinreich et al., 2021). This finding is consistent with earlier observations of symptom resolution preceding antibody-positive responses in those patients that have recovered from mild illness (Wajnberg et al., 2020b). Antibody-mediated pathogen clearance through the complement pathway could be a double-edged sword because of the accompanying adverse inflammatory cytokine responses. Therefore, determining whether there is a consistent association between high levels of $\mathrm{nAb}$ and severe COVID-19 in relation to the complement pathway might be therapeutically important (Santiesteban-Lores et al., 2021).

Unlike with other viruses, such as the influenza virus that have infected humans for many years, the protective ability of $\mathrm{nAb}$ titers against SARS-CoV-2 has yet to be established (Krammer, 2020, 2021). However, it should not be considered possible for COVID-19 convalescents that possess $\mathrm{nAb}$ to become reinfected with the same strain of SARS-CoV-2 and develop COVID-19 again (Baumgarth et al., 2020). However, those naturally infected with SARS-CoV-2 might become reinfected. Although reinfections appear mostly asymptomatic (Lumley et al., 2021), more severe disease after reinfection cannot be ruled out. Drastic reduction of viral titer after $\mathrm{nAb}$ treatment as mentioned above suggests protective role of $\mathrm{nAb}$, if present in enough concentration, against infection.

\section{Immune Responses to COVID-19 Vaccines}

The WHO EUL COVID-19 vaccines (https://extranet.who. int/pqweb/vaccines/covid-19-vaccines; last accessed on November 9,2021 ) are classified into three types: mRNA, adenovirus-vectored, and inactivated-virus vaccines. In comparison to these vaccines, inactivated-virus vaccines (IVVs) use an established technology and have been used against many viruses including influenza viruses, hepatitis A virus, and poliovirus. Indeed, mRNA and adenovirus-vectored vaccines are newly approved technologies (Angeli et al., 2021; Gebre et al., 2021). Two EUL IVVs were derived from SARSCoV-2 strains isolated in China (Wang et al., 2020); these were developed by Sinopharm and Sinovac. Replication-incompetent adenovirus-vectored vaccines, ChAdOx1 nCoV19 and Ad26.COV2.S, were developed by AstraZeneca and Janssen Pharmaceutical Company of Johnson \& Johnson, respectively, and the BNT162b2 mRNA vaccine was developed by Pfizer/BioNTech using codon optimization of the fulllength $S$ amino acid sequence based on the genome sequence of the first isolate of the SARS-CoV-2 virus from Wuhan with two amino acids substitutions, K986P and V987P, in the S2 domain for stabilization of prefusion conformation (Folegatti et al., 2020; Jackson et al., 2020; Mulligan et al., 2020; Walsh et al., 2020; Wu et al., 2020; Sadoff et al., 2021). The mRNA-1273 vaccine by Moderna was also developed using a full-length SARS-CoV-2 sequence, most likely from the earliest isolates with two amino acids substitutions, as with the BNT162b2 mRNA vaccine. Except for the IVVs, all EUL vaccines express the full-length $S$ protein of SARS-CoV-2 on the membrane of the cell that takes up the mRNA-lipid nanoparticle (mRNA-LNP) or is infected with the adenovirus vector. Phase I/II clinical trial assessments of the immune responses of the EUL vaccines are summarized in Table 1.

COVID-19 vaccine design was likely to have been based on

Table 1. Phase I/II clinical trial assessments of immune responses related to EUL vaccines

\begin{tabular}{|c|c|c|c|}
\hline Vaccine (Reference) & Administration & Antibody response & T-cell response \\
\hline $\begin{array}{l}\text { mRNA-1273 of Moderna } \\
\text { (Jackson } \text { et al., 2020) }\end{array}$ & $\begin{array}{l}\text { Membrane } S \text { protein-encoding } \\
\text { mRNA-LNP, } 100 \mu \mathrm{g} / \text { dose } \\
2 \text { doses } 28 \text { days apart }\end{array}$ & $\begin{array}{l}\mathrm{nAb} \text { after first dose: low response } \\
\mathrm{nAb} \text { after second dose: mean } \mathrm{ID}_{50} \text { titer } \\
\text { higher than that of HCS at } 7 \text { days post } \\
\text { second dose }\end{array}$ & $\begin{array}{l}\text { Strong Th1 skewed } \mathrm{CD} 4^{+} \text {and low } \mathrm{CD} 8^{+} \\
\text {T-cell responses against } \mathrm{S} \text { protein at } 14 \\
\text { days post second dose }\end{array}$ \\
\hline $\begin{array}{l}\text { BNT162b2 of } \\
\text { Pfizer/BioNTech } \\
\text { (Walsh } \text { et al., 2020) }\end{array}$ & $\begin{array}{l}\text { Membrane } S \text { protein-encoding } \\
\text { mRNA-LNP, } 30 \mu \mathrm{g} / \text { dose } \\
2 \text { doses } 21 \text { days apart }\end{array}$ & $\begin{array}{l}\mathrm{nAb} \text { after first dose: low response } \\
\mathrm{nAb} \text { after second dose: } \mathrm{IC}_{50} \mathrm{GMT} \\
\text { 1.5-3.6-fold of HCS at } 7 \text { days post second } \\
\text { dose }\end{array}$ & Not measured \\
\hline $\begin{array}{l}\text { ChAdOx1 nCoV-19 of } \\
\text { AstraZeneca } \\
\text { (Folegatti } \text { et al., 2020) }\end{array}$ & $\begin{array}{l}\text { Membrane } S \text { protein-encoding } \\
\text { ChAdOx } 1 \text { vector, } 5 \times 10^{10} \\
\text { VP/dose } \\
2 \text { doses } 28 \text { days apart }\end{array}$ & $\begin{array}{l}\text { nAb after first dose: } 91 \% \text { seroconversion } \\
(\text { PHE MNA } \\
\text { day } 28 \\
\text { nAb after second dose: } 100 \% \\
\text { seroconversion (PHE MNA } \\
136,115-241 \text { ) after second dose } \\
\text { IC }_{50} \text { titers similar with } \mathrm{HCS} \\
\end{array}$ & $\begin{array}{l}\text { IFN } \gamma \text { ELISpot response against S protein } \\
\left(\mathrm{CD} 4^{+} \text {or CD } 8^{+} \mathrm{T} \text { cell not known) at day } 7\right. \\
\text { peak at day } 14 \text { (median } 1642,1423-2009 ; \\
\text { baseline } 108,90-150) ; \text { no change after } \\
\text { second dose. }\end{array}$ \\
\hline $\begin{array}{l}\text { Ad26.COV2.S of Janssen } \\
\text { (Sadoff et al., 2021) }\end{array}$ & $\begin{array}{l}\text { Membrane } S \text { protein-encoding } \\
\text { Ad26 vector, }>8.92 \log _{10} \mathrm{IU} \\
\left(5 \times 10^{10} \mathrm{VP}\right) / \text { dose a single dose }\end{array}$ & $\begin{array}{l}\text { nAb after first dose: } 99 \% \text { seroconversion } \\
\text { (IC } \text { F }_{50} \text { GMT 224, 168-298) at day 29. 100\% } \\
(310,228-422) \text { at day 57. HCS GMT 522 } \\
\text { nAb after second dose: no second dose }\end{array}$ & $\begin{array}{l}\text { IFN } \gamma \text { expressing } \mathrm{S} \text { peptide specific } \mathrm{CD}^{+} \\
\text {and } \mathrm{CD} 8^{+} \mathrm{T} \text { cells in } 76 \% \text { and } 51 \% \text {, } \\
\text { respectively at day } 15\end{array}$ \\
\hline $\begin{array}{l}\text { CoronaVac of Sinovac } \\
\text { (Zhang et al., 2021) }\end{array}$ & $\begin{array}{l}\text { Inactivated SARS-CoV- } 2 \text { antigen, } \\
600 \mathrm{SU}(3 \mu \mathrm{g}) / \text { dose } 2 \text { doses } 28 \\
\text { days apart. }\end{array}$ & $\begin{array}{l}\text { nAb after first dose: } 97 \% \text { seroconversion at } \\
\text { day } 28 \text { (no GMT data, no GMT basis) } \\
\text { nAb after second dose: } 97 \% \\
\text { seroconversion (GMT 44.1) at } 28 \text { days post } \\
\text { second dose } \\
\text { HCS GMT } 163.7\end{array}$ & $\begin{array}{l}\text { T-cell responses measured using IFN } \gamma \\
\text { ELISpot were low }\left(\mathrm{CD}^{+} \text {or } \mathrm{CD} 8^{+} \mathrm{T} \text { cell }\right. \\
\text { not known) }\end{array}$ \\
\hline
\end{tabular}


studies of antigenicity in immune responses against SARSCoV (Li et al., 2008; Du et al., 2009). A study by Li et al. (2008) in which the T-cell responses of SARS convalescents were analyzed for antigen specificity appears especially relevant. It showed that the $\mathrm{S}$ protein of SARS-CoV was significant for $\mathrm{B}$ - and $\mathrm{T}$-cell antigens; $\mathrm{CD} 4^{+} \mathrm{T}$-cell responses were mainly against the $\mathrm{S}$ protein, whereas $\mathrm{CD}^{+} \mathrm{T}$-cell responses were across the SARS-CoV proteome, although the proportion of $\mathrm{S}$ proteins recognizing $\mathrm{CD}^{+} \mathrm{T}$ cells was still relatively high. This study suggests that the dominant antigen $\mathrm{S}$ protein alone could potentially produce $\mathrm{nAb}$ response, $\mathrm{CD}^{+}$and $\mathrm{CD}^{+} \mathrm{T}$ cell responses almost identical to the immune responses to SARS-CoV infection. In an animal experiment, it was shown that a DNA vaccine encoding the fulllength S protein of SARS-CoV could induce both T-cell and $\mathrm{nAb}$ responses and thereby provide protective immunity ( $\mathrm{Du}$ et al., 2009). The mRNA and adenoviral-vectored vaccines encoding the full-length $S$ protein of SARS-CoV-2 appear to have been designed for similar $\mathrm{nAb}$ and $\mathrm{T}$-cell responses.

Cellular antigens directly presented on major histocompatibility complex (MHC) type I (MHC I) from de novo synthesis are cytosolic proteins as well as the signal peptides of the secreted and membrane proteins rather than the secreted proteins and membrane proteins themselves (Del Val et al., 2020). Therefore, the membrane $S$ protein of SARS-CoV must be cross-presented on MHC I of dendritic cells (DCs) by a phagosome and a toll-like receptor (TLR) signal-mediated pathway (Nair-Gupta et al., 2014; Sengupta et al., 2019; Colbert et al., 2020). Antigen-presenting cells (APCs) do not express ACE2; moreover, SARS-CoV-2 infection to DCs using any other receptor than ACE2 has not been established (Campana et al., 2020). Antibody-dependent enhancement (ADE) of the infection mechanism could be a substitute for the requirement of ACE2 in DC infection. There have been reports of no detection of ADE of SARS-CoV-2 infection (Kim et al., 2021; Zheng et al., 2021). On the other hand, detection of $\mathrm{ADE}$ of SARS-CoV-2 infection in vitro but no enhancement of disease in vivo has been reported (Li et al., 2021a). Since the ADE of SARS-CoV and Middle East respiratory syndrome coronavirus infection and $S$ protein-containing pseudovirus infections to $\mathrm{Fc}$ receptor ( $\mathrm{FCR}$ )-expressing cells have been observed in terms of de novo viral protein synthesis (Jaume et al., 2011; Wan et al., 2020b), further studies on ADE of SARSCoV-2 infection according to de novo viral protein synthesis rather than progeny virion production remain necessary.

Here, we consider whether the presence of S protein-responsive $\mathrm{CD}^{+} \mathrm{T}$ cells could be useful as cytotoxic T lymphocytes (CTLs) for clearing SARS-CoV- or SARS-CoV-2infected cells. As discussed earlier, de novo synthesized $\mathrm{S}$ protein, which is a transmembrane protein, might not be presented on MHC I of the infected cell; thus, the infected cell might not be a target of S protein-specific $\mathrm{CD}^{+}$CTLs. It appears that $\mathrm{CD} 8^{+} \mathrm{T}$-cell responses against cytosol-expressed proteins, such as the $\mathrm{N}$ protein and nonstructural proteins, could play a more critical role in clearing the infected cells. The presence of $\mathrm{CD}^{+} \mathrm{T}$-cell responses against the whole proteome of SARS-CoV in SARS convalescents (Li et al., 2008) appears to be a more logical outcome.

One question remains: where did the MHC I antigen come from in the SARS convalescent cases? Cross-presentation of
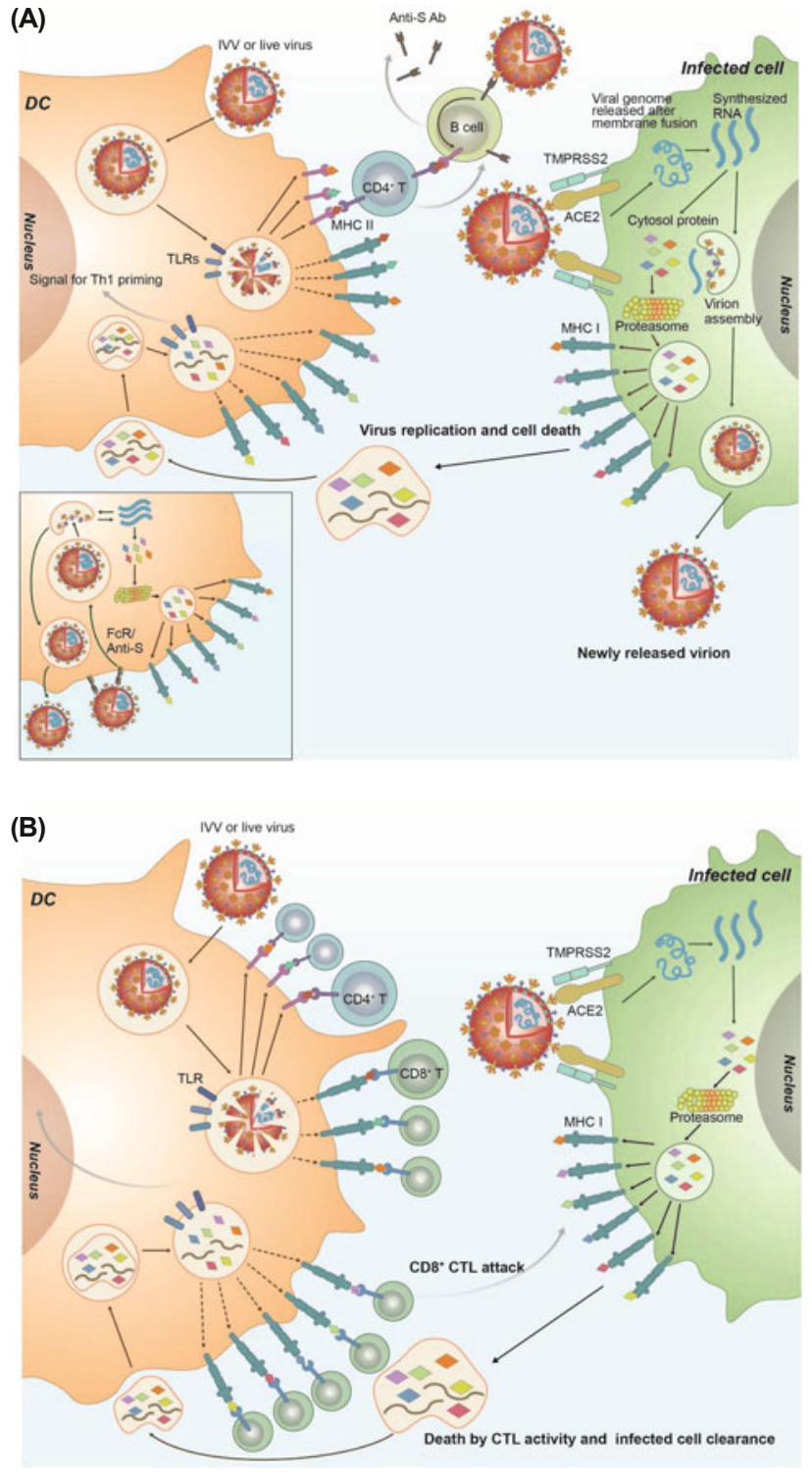

Fig. 1. Conceptualization of immune responses against SARS-CoV or SARSCoV-2. (A) Acute phase of SARS-CoV or SARS-CoV-2 infection. Since SARS-CoV or SARS-CoV-2 does not infect antigen-presenting cells, the virion particles and dead cell fragments generated by the infected cells might be the source of antigens for presentation on major histocompatibility complex (MHC) II and cross-presentation on MHC I of dendritic cells (DCs). The virion particles may be taken up by the dominant antigen $S$ protein-specific B cells and the structural proteins will be presented on MHC II of B cells, which will secure the help of structural protein-specific $\mathrm{CD} 4^{+} \mathrm{T}$ cells (only S protein-specific $\mathrm{CD} 4^{+} \mathrm{T}$ cell help is depicted for simplicity). Although the MHC I antigen source may be largely cross-presentation of the infected cell fragments, non-nAb capacity antibodies might be utilized for antibody-dependent enhancement of DC infection, providing MHC I with de novo synthesized cytosolic antigens (shown in boxed section). EUL inactivated-virus vaccines might be similar to the live virus for MHC II antigen presentation except for the limited duration of the antigens, but they are essentially different in relation to the MHC I antigen because of the lack of dead cell fragments. (B) Infection clearance of SARS-CoV or SARS-CoV-2 infection. CD8 ${ }^{+}$CTLs generated through the process depicted in (A) might clear the infected cells before releasing virion progeny from the infected cells. Pathways leading to the lysosome and antigen presentation on MHC I and MHC II are indicated by arrows. TLR signal-mediated antigen cross-presentation to MHC I is indicated by dotted arrows. Expression of antigens from dead infected cell fragments on MHC II of DC is omitted for simplicity. Molecules and cells are not drawn to scale. 
the proteins from the uptaken virion would have activated $\mathrm{CD}^{+} \mathrm{T}$ cells specific to only the structural proteins, such as the $\mathrm{S}, \mathrm{M}$, and $\mathrm{N}$ proteins (not enough of the $\mathrm{E}$ protein is present), and only $\mathrm{N}$ protein-specific $\mathrm{CD} 8^{+} \mathrm{CTL}$ would have been effective at clearing the infected cells by recognizing cytosol-expressed N proteins presented on MHC I of the infected cells. The diversity of $\mathrm{CD}^{+} \mathrm{T}$-cell responses in the SARS convalescents most likely originated from the crosspresentation of dead infected and dead cell fragments containing diverse cytosol-expressed SARS-CoV antigens (Fig. 1A). Indeed, a high frequency of IFN $\gamma$-expressing $\mathrm{T}$ cells specific to de novo expressed viral proteins, such as ORF7 and ORF8 proteins of SARS-CoV-2 in the acute phase, was associated with mild COVID-19, whereas low T-cell responses with specificity predominantly related to the structural proteins was associated with severe COVID-19 (Tan et al., 2021). Another plausible mechanism of cytosol-expressed SARS$\mathrm{CoV}$ antigen presentation on MHC I of DC was ADE of DC infection by SARS-CoV, which could have occurred at a certain point over the course of infection when the $S$ proteinspecific antibody concentration was ideal for ADE of SARS$\mathrm{CoV}$ infection (Fig. 1A). It is plausible that lower $\mathrm{nAb}$ titers consistently observed in unhospitalized mild COVID-19 patients relative to those observed in hospitalized patients might have been due to the antibody level being optimal for $\mathrm{ADE}$ of DCs and diverse cytosol-expressed SARS-CoV-2 proteinspecific $\mathrm{CD}^{+}$CTL generation. Clearance of infected cells could eventually result in depletion of the antigen source, which would slow down further nAb responses. Although the $\mathrm{CD}^{+} \mathrm{T}$ cells responding against the membrane proteins, such as the $\mathrm{S}$ and $\mathrm{M}$ proteins, might not be effective for clearing infected cells, they would participate in skewing CD $4^{+}$ T-cell responses to Th1 types by secreting IFN $\gamma$ (Gajewski and Fitch, 1988) (Fig. 1B). Indeed, generation of SARS-CoV $S$ protein-specific $\mathrm{CD} 8^{+} \mathrm{T}$-cell memory alone was found to be primarily, although not completely, protective in SARSCoV-challenged mice (Channappanavar et al., 2014); however, this study did not show whether the viral titer reduction in the challenged mice at seven days post-infection was directly caused by $\mathrm{S}$ protein-specific $\mathrm{CD} 8^{+} \mathrm{CTL}$ activity.

Intramuscular-injected antigens are expected to be taken up mainly by APCs at the vaccine injection site (Fig. 2A). The inactivated whole-virion, mRNA-LNP, and the adenoviralvectored vaccines might be the preferred size for macropinocytosis- or phagocytosis- mediated uptake by APCs such as DCs, monocytes, and macrophages (Frenz et al., 2015). The difference between inactivated whole-virion particles and mRNA-LNP or adenoviral-vectored vaccines is that the $S$ protein cannot be presented as an antigen on DCs directly when using mRNA-LNPs or adenovirus vectors through the lysosomal pathway. mRNA-LNPs are designed for endosomal fusion of the LNP and delivery of mRNA to the cytosol (Buschmann et al., 2021) leading to $S$ protein expression as an antigen. However, adenovirus particles that are macropinocytosed or phagocytosed by APCs without specific receptor-mediated uptake might be destroyed in the lysosome and would therefore be unable to deliver $\mathrm{S}$ protein-encoding DNA to the nucleus, which in turn would lead to the lack of $S$ protein expression as an antigen. In contrast, adenoviral vector proteins processed in the lysosome might be pre-
(A)

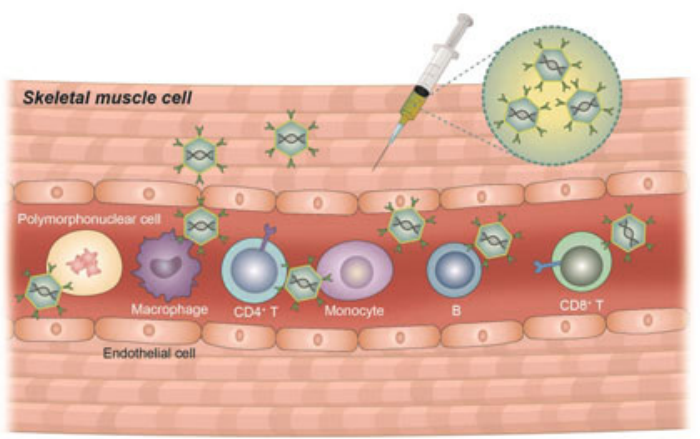

(B)
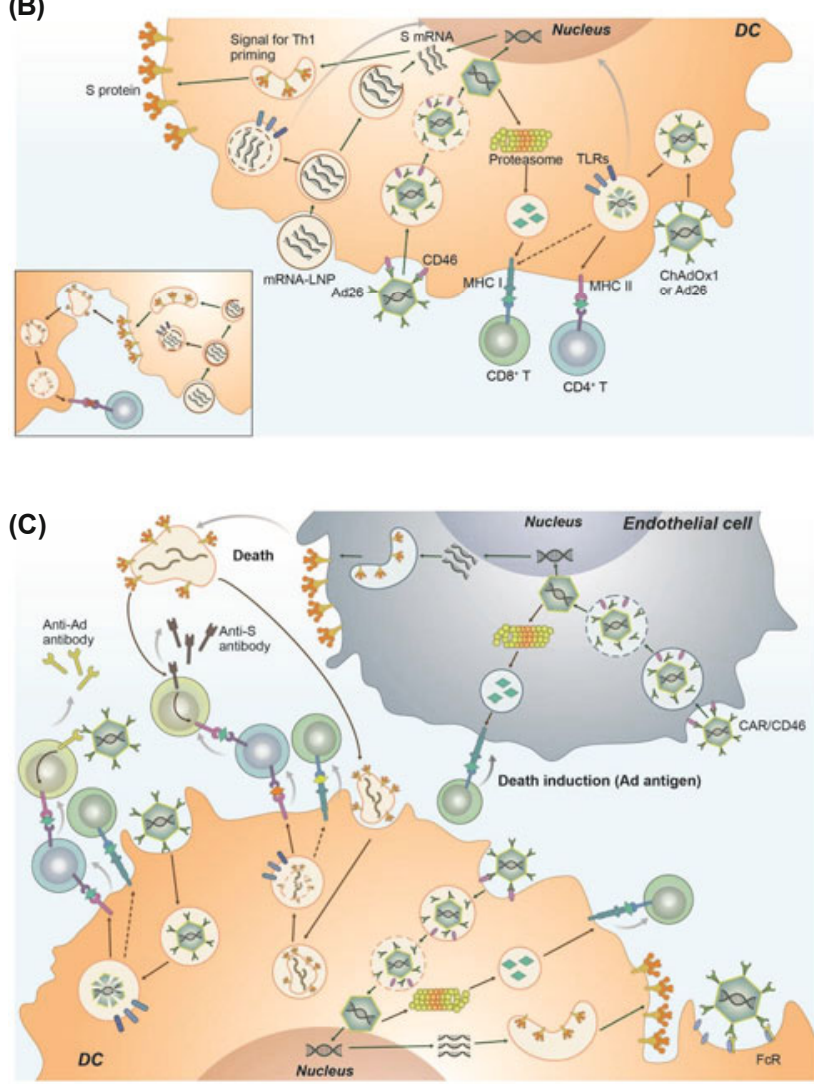

Fig. 2. Conceptualization of antigen-presentation pathways in dendritic cells (DCs) via mRNA-LNP and adenovirus-vectored vaccines. (A) An illustration of immune cells in the intramuscular injection site. Multinucleated skeletal muscle cells, DCs, and other innate and adaptive immune cells circulating in the muscle blood vessel lined with endothelial cells are depicted (Pillon et al., 2013). Injury by injection recruit innate immune cells to the intramuscular site. (B) Antigen-presentation pathways to MHC I and MHC II in DCs and T-cell activation. Green arrows indicate signal pathways leading to the expression of the S protein on the cell membrane. Colored symbols, objects, and arrows are the same as those used in Fig. 1. The S protein expressed from mRNA-LNP or the adenovirus vector can be presented to MHC II only by uptake of membrane vesicles released by the DCs (shown in boxed section) or dead cell fragments. (C) Adenovirusspecific $\mathrm{CD}^{+}$CTLs activated as shown in (B) attack adenovirus vectorinfected cells. The DCs can take up dead cell fragments for S protein antigen presentation on MHC II, S protein-specific CD4 ${ }^{+}$T-cell activation, subsequent $\mathrm{S}$ protein-specific B-cell activation, antibody production, and $\mathrm{S}$ protein antigen cross-presentation on MHC I. The ChAdOxl-vectored vaccine can mimic the Ad26-vectored vaccine after the second dose via the antibody-dependent enhancement of infection to DCs in the presence of anti-ChAdOx1 antibody (Valliyott et al., 2020). Cells and molecules are not drawn to scale. 
sented as antigens directly on APCs. Similar to IVVs, pathogen-induced innate immune signals used to prime APCs might come from the RNA and DNA of mRNA-LNPs and adenoviral particles that have failed to escape the endosome and have ended up in the late endosome/lysosome, respectively (Kawai and Akira, 2008; Farkas and Kemény, 2011; Leifer and Medvedev, 2016; Pardi et al., 2018; Teijaro and Farber, 2021) (Fig. 2B).

\section{Immune Responses to Inactivated SARS-CoV-2 Vaccine}

Because SARS-CoV-2 does not infect DCs, inactivated SARSCoV-2 vaccines can be considered similar to live SARSCoV-2. However, SARS-CoV-2 IVVs and live SARS-CoV-2 are expected to induce different immune responses in terms of the magnitude of $\mathrm{B}$ - and $\mathrm{CD} 4{ }^{+} \mathrm{T}$-cell activation and the diversity of $\mathrm{CD}^{+} \mathrm{T}$-cell responses. The source of SARSCoV-2 antigens for presentation on MHC I and MHC II of DCs is direct virion particle uptake only with IVVs; however, dead infected cell fragments might also be available during natural infection (Fig. 1). Consistent with this notion, the $\mathrm{nAb}$ response against CoronaVac was much lower than that in human convalescent sera (Table 1). In terms of CD8 ${ }^{+}$ $\mathrm{T}$-cell responses, only the structural $\mathrm{S}, \mathrm{M}$, and $\mathrm{N}$ proteins would be cross-presented on MHC I of DCs in IVV-vaccinated individuals, whereas diverse cytosol-expressed SARSCoV-2 antigens from dead cell fragments might be crosspresented in those that were naturally infected (Fig. 1).

Furthermore, the presence and absence of persistent antigens in SARS-CoV-2 natural infection and IVV, respectively, would determine the degree of T-cell responses. The result of phase I/II clinical trials of CoronaVac have shown low IFN $\gamma$ expressing SARS-CoV-2-specific T-cell responses (Table 1) consistent with this notion. Such low IFN $\gamma$-expressing T-cell responses after vaccination with CoronaVac IVV suggest that a Th2-skewed T-cell response may have occurred. Higher Th2 responses were observed in fatal SARS and COVID-19 cases (Li et al., 2008; Vaz de Paula et al., 2020). A study using inactivated SARS-CoV vaccine showed the presence of Th2type immunopathology after challenge with SARS-CoV in immunized mice (Tseng et al., 2012). The possibility that a similar immunopathology would occur when an IVV-vaccinated individual becomes infected with SARS-CoV-2 is concerning.

\section{Immune Responses to mRNA-LNP and Adenovirus- Vectored SARS-CoV-2 Vaccines}

mRNA-LNPs do not require a receptor for internalization and delivery of mRNA to the cytosol (Hou et al., 2021). However, the adenovirus that infects the target cell via a specific receptor can only deliver the antigen-encoding DNA to the nucleus. It is worthwhile to consider whether DCs express receptors for the adenovirus vectors. The adenovirus vectors of Janssen and AstraZeneca vaccines are human adenovirus serotype 26 (Ad26) and chimpanzee adenovirus-derived ChAdOx1, respectively (Folegatti et al., 2020; Sadoff et al.,
2021). Ad26 utilizes CD46 as a primary receptor (Li et al., 2012), whereas ChAdOx1, which is grouped similarly to human adenovirus serotype E (Morris et al., 2016), uses the coxsackie adenovirus receptor (CAR) in the same manner as human adenovirus serotype E (Roelvink et al., 1998). CD46 is expressed ubiquitously in human cells (Cardone et al., 2011); in contrast, CAR is present in heart tissue, brain tissue, and epithelial and endothelial cells (Morris et al., 2016), but it is not expressed sufficiently in DCs (Mizuguchi and Hayakawa, 2004). Mature skeletal muscle cells express CAR and CD46 at low levels and are poorly transduced by adenoviruses (Larochelle et al., 2008). It is possible for Ad26 that utilizes CD46 to transduce DCs, endothelial cells, and many other types of cells. Given the universality of Ad26 receptor CD46 expression, the Ad26 target cell might be as universal as the mRNA-LNPs and furthermore take up Ad26 more readily than the mRNA-LNPs via receptor binding. However, endothelial cells are most likely cells to be transduced by ChAdOx1 that utilizes CAR at the site of the intramuscular injection or elsewhere.

Given the expression profile of the adenovirus receptor, the source of the $\mathrm{S}$ protein antigen generated by ChAdOx1 $\mathrm{nCoV}-19$ vaccination appears to be dead cell fragments likely originating from infected endothelial cells (Fig. 2B and 2C). The sequence of events after the intramuscular injection of ChAdOx1 nCoV-19 is thought to be as follows: (i) an immune response to ChAdOx1, (ii) a ChAdOx1-specific CD8 ${ }^{+}$ CTL attack on ChAdOx1 nCoV-19-infected endothelial cells, (iii) uptake of the S protein-containing dead endothelial cell fragments and antigen presentation by APCs, and (iv) S protein-specific immune responses such as $\mathrm{S}$ protein-specific $\mathrm{B}$-cell and $\mathrm{CD} 4^{+} / \mathrm{CD}^{+} \mathrm{T}$-cell responses. Although the early gene products of adenoviruses suppress MHC I antigen presentation in the infected cell resulting in CTL evasion (Wold and Ison, 2013), ChAdOx1 nCoV-19 is devoid of genes that express proteins with such functions (Almuqrin et al., 2021). Therefore, exogenous adenovirus proteins might be presented on MHC I of the infected endothelial cells without suppression. The characterization of the adenovirus vector escaping the endosome through endosomal lysis (Masters and Perlman, 2013) provides processing of the adenoviral proteins that access the cytosol and proteasome for MHC I presentation during stage (ii) in the sequence described above. The sequence of events after the intramuscular injection of Ad26. COV2.S is likely to be similar to that for ChAdOx1 nCoV-19 in terms of CTL-mediated S protein cross-presentation on MHC I of DCs (Fig. 2C). The immune response to replication incompetent Ad26 has been shown to be Th1-skewed (Li et al., 2012). Additionally, a clinical trial showed that vaccination with ChAdOx1 nCoV-19 induced a Th1-biased response (Folegatti et al., 2020; Ewer et al., 2021). The immune response to the ChAdOxl vector itself would likely involve the Th1 type, as with Ad26. Overall, adenovirus-specific Th1 responses might help facilitate the generation of Th1-type $\mathrm{T}$-cell responses against the $\mathrm{S}$ protein after ChAdOx1 nCoV-19 or Ad26.COV2.S vaccination (Folegatti et al., 2020; Sadoff et al., 2021).

mRNA-LNP and adenovirus-vectored vaccines are similar to live virus vaccines in terms of antigen persistence. Nonetheless, they are not specifically live virus vaccines without 
direct presentation of the target antigen on MHC II of DCs. It is unclear how membrane-expressed $S$ protein could be available as an antigen without CTL-involved dead cell fragment generation. DCs are known to release plasma membrane particles or vesicles (Théry et al., 2009). An S proteincontaining membrane vesicles (MVEs) released by $S$ proteinexpressing DCs is the most likely source of the $S$ protein antigen presented on the MHC II of DCs (Fig. 2B). Immune responses from mRNA-LNP and Ad26- and ChAdOx1-vectored vaccines would depend on the abundance and duration of the $S$ protein antigen source, which could include MVEs from DCs only, MVEs from DCs plus dead cell fragments, or dead cell fragments only (Fig. 2B and 2C).

Although the vaccines are expected to be largely taken up by APCs at the site of the injection, intramuscularly injected mRNA-LNP and adenovirus vector have been shown to spread systemically, with mRNA-LNP doing so to a greater degree than adenovirus vector, in mice (Pardi et al., 2015; Liu et al., 2017). For mRNA-LNPs, the expression of the encoded gene waned by day eight post-injection, with the most robust expression occurring during day 1 in the liver (Pardi et al., 2015). In contrast, intramuscular injection of a replication-incompetent Ad5, which uses the same receptor as ChAdOx1, showed the highest expression of the encoded gene in mice at the injection site during day 1 , and then several days of solid expression in the liver around days 6-9, followed by weak but persistent expression at the injection site even up to day 35 (Liu et al., 2017). Intramuscularly injected ChAdOx1 and Ad26 might traffic in a similar manner and show similar encoded gene expression duration to that of Ad5. Prolonged expression of the encoded antigen in adenovirus-infected cells suggests that a potentially sustained release of the $S$ proteincontaining MVEs occurs from DCs infected with Ad26.COV2.S. Even in terms of the persistence of MVEs as the only source of the antigen, the immune response from Ad26.COV2.S vaccination is postulated to be stronger than that from mRNALNPs. For ChAdOx1 nCoV-19, despite the expression of the $S$ protein in the infected cells potentially persisting, the availability of the $S$ protein antigen as dead cell fragments is likely to be limited by the availability of ChAdOxl antigen on MHC I of the infected cells as the specific CTL target (Fig. 2C).

Encoded $S$ protein antigen presentation from mRNA-LNP vaccines involves two nonspecific steps: uptake of (a) the initial vaccine particle and (b) the membrane $S$ protein containing fragment/vesicle. In contrast, step (b) is the only nonspecific step in the adenovirus-vectored vaccines. Consistently, the $\mathrm{nAb}$ responses of mRNA-LNPs after the first dose were relatively low compared to those of ChAdOx1 nCoV-19 after the first dose (Table 1). The "explosion" of nAb responses after the second dose of mRNA-LNPs might be due to enhanced uptake of the S protein-containing MVEs by the FcR-bearing DCs due to the assistance of low levels of S protein-specific antibodies generated from the first dose. The "explosion" of $\mathrm{nAb}$ responses in the heterologous vaccination of mRNALNPs after the first ChAdOx1 nCoV-19 dose compared with after two doses of the ChAdOx1 $\mathrm{nCoV}-19$ vaccination (Schmidt et al., 2021) might similarly be due to existing $S$ proteinspecific antibodies from the first dose of ChAdOx1 nCoV-19. The lack of such a dramatic enhancement of $n A b$ response between first and second doses of ChAdOx1 nCoV-19 might be due to high anti-vector antibody induced by the first dose (Stephenson et al., 2021). Whether it occurs by vector antibody-FcR-mediated destruction of ChAdOx1 nCoV-19 particles or by ADE of DC infection (Fig. 2C), endothelial cell infection as the membrane $S$ protein antigen source might be primarily averted with the second dose. Indeed, for Ad26. COV2.S vaccination, the second dose does not enhance the nAb response (Stephenson et al., 2021).

Since MVEs from DCs are less likely to contain TLR ligands, the S protein in MVEs is not likely cross-presented efficiently on MHC I of DCs. After mRNA-1273 vaccination, the $\mathrm{S}$ protein-specific $\mathrm{CD}^{+} \mathrm{T}$-cell response has consistently been reported as low (Table 1). However, as discussed earlier, the $\mathrm{S}$ protein-specific $\mathrm{CD} 8^{+} \mathrm{CTL}$ does not have an available target; thus, the effect of the inadequate $\mathrm{CD}^{+} \mathrm{T}$-cell response is likely to be relatively small. Indeed, robust IFN $\gamma^{+}$Th1 $\mathrm{CD} 4^{+} \mathrm{T}$-cell responses would compensate, functionally, for low levels of $\mathrm{CD}^{+} \mathrm{T}$ cells as the source of IFN $\gamma$, as was observed with mRNA-1273 vaccination (Table 1 ).

\section{Rare Recapitulation of COVID-19 in COVID-19 Vaccine Recipients}

Given the collected evidence, we can rationally deduce that a stronger $\mathrm{S}$ protein-specific $\mathrm{nAb}$ response from the first dose of ChAdOx1 nCoV-19 should originate from more endothelial cell infections as the source of the $\mathrm{S}$ protein antigen containing membrane fragments. If endothelial cell infection and endotheliopathy are vital factors in the COVID-19 vasculopathy (Goshua et al., 2020; O'Sullivan et al., 2020; Varga et al., 2020), we speculate about the reason for adverse effects. Because of the replication incompetency of the adenovirus vectors, the number of virus particles per target cell will be limited. Therefore, assuming the same amount of infectious vaccine (Table 1), endothelial cell infection caused by ChAdOxlis predicted to be greater than that caused by Ad26 since infection with the latter would include distribution to many cell types other than endothelial cells.

Although high titers of autoantibodies against platelet factor- 4 have been shown to be present and widespread in vaccine-induced thrombotic thrombocytopenia (VITT) (Greinacher et al., 2021; McGonagle et al., 2021), the mechanism underlying the occurrence of VITT is unclear. In a few VITT cases, cerebral venous sinus thrombosis (CVST) in the portal, splanchnic or hepatic veins, deep venous thrombi, pulmonary emboli, and acute arterial thromboses were reported (Cines and Bussel, 2021). Interestingly, thromboses are relatively common among severe COVID-19 patients (Fraiman et al., 2020; Favaloro et al., 2021); thus, VITT could be considered a rare recapitulation of severe COVID-19.

The European Medicines Agency reported possible VITT cases, including at least 169 possible cases of CVST and 53 potential cases of splanchnic vein thrombosis, among 34 million recipients of the $\mathrm{ChAdOx} 1 \mathrm{nCoV}-19$ vaccine. Additionally, 35 probable cases of central nervous system thrombosis were found among 54 million recipients of the Pfizer/BioNTech mRNA vaccine, 5 possible cases of CVST were reported among 4 million recipients of the Moderna mRNA vaccine, and 6 possible cases of CVST were recognized among more than 
7 million recipients of the Ad26.COV2.S vaccine. The incidence of CVST in the general population is estimated at 0.22 to 1.57 cases per 100,000 people per year (Cines and Bussel, 2021). Thus, the number of cases of CVST among vaccinated individuals is not higher than the estimated incidences in the general population per year, with the possible exception of those vaccinated with ChAdOx1 nCoV-19 for which incidences are higher than the lower estimate and lower than the higher estimate of incidences in the general population per year. However, the number of individuals vaccinated with Ad26.COV2.S is low compared with those vaccinated with ChAdOx1 nCoV-19 and comparisons between these two vaccines must be made with caution. Nevertheless, it appears that the rate of CVST incidences among ChAdOx1 nCoV-19-vaccinated patients is comparatively higher than in those vaccinated with Ad26.COV2.S. This seems to be consistent with our reasoning based on the distribution of the vaccine infection target cells. However, 202 possible cases of VITT in 34 million recipients of the ChAdOx $1 \mathrm{nCoV}-19$ vaccine (about 6 cases per million) is a very small number compared with more than 4 million deaths from 200 million confirmed cases of COVID-19 (> 20,000 deaths per million infected).

\section{Strategy to Cope with Further SARS-CoV-2 Variants of Concern}

Earlier, we discussed how nAb levels might not be robustly correlated with immune protection. Conversely, the protective efficacy against "variants of concern" (VOCs) may not be significantly affected by $\mathrm{nAb}$ titer reduction. The current EUL vaccines based on very early isolates of SARS-CoV-2 are known to lack efficacy against the highly transmissible $\beta$ and $\delta$ VOCs in terms of $n A b$ response (Garcia-Beltran et al., 2021; Wall et al., 2021a, 2021b). However, S protein-specific $\mathrm{CD}^{+}$and $\mathrm{CD}^{+} \mathrm{T}$-cell responses induced by the mRNA vaccine are reduced minimally against the $S$ proteins from these VOCs (Alrubayyi and Peppa, 2021; Tarke et al., 2021). We also previously mentioned that the $S$ protein-specific $\mathrm{CD}^{+} \mathrm{T}$ cells generated by $\mathrm{S}$ protein-targeting vaccines might not effectively clear the infected cells. Because of reduced nAb activity and ineffective $S$ protein-specific $\mathrm{CD}^{+} \mathrm{CTL}$ activity, breakthrough infections of the currently dominant SARSCoV-2 $\delta$ VOC as well as emerging VOCs are highly likely in those who are already vaccinated. However, it is also possible that the $\mathrm{S}$ protein-specific memory $\mathrm{CD}^{+}$and $\mathrm{CD}^{+} \mathrm{T}$-cell responses, which are barely reduced against VOC $S$ proteins, would be rapidly deployed for Th1-type immune responses and could help facilitate VOC S protein-specific B-cell responses. The antibodies from the vaccination might not be as effective in terms of neutralizing the VOCs but they may participate in the ADE of DC infection with the VOCs for the efficient generation of CD8 ${ }^{+} \mathrm{CTL}$ against diverse cytosolexpressed VOC SARS-CoV-2 proteins and thereby help clear the infected cells (Fig. 1). Indeed, anti-S protein seropositive reinfected cases confirmed by PCR tests appear to be asymptomatic (Lumley et al., 2021). DCs infected with SARS-CoV-2 by ADE are presumably similar to FCR-bearing cells infected with SARS-CoV by ADE, which synthesize viral proteins without viral progeny production and therefore without the po- ssibility of enhancing disease (Jaume et al., 2011).

VOCs appear rapidly. Although some vaccines are still considered effective against such VOCs, these judgments have been based not on evidence from clinical trials but on laboratory data. Of course, conducting clinical trials to test for the efficacy of EUL vaccines against continuously appearing VOCs is impracticable. Under these circumstances, a full review on the effectiveness of emergency authorized vaccines and affirmation of the authorization of the effective vaccine platform followed by the encoded antigen replacement might be a more practical strategy. The example of the 2009 H1N1 influenza pandemic vaccine approval without clinical studies under the condition that the new monovalent vaccine follows the protocol previously established for seasonal vaccine production (https://www.fda.gov/vaccines-blood-biologics/ vaccines/influenza-h1n1-2009-monovalent-vaccines-questions-and-answers; last accessed on November 9, 2021) might be applied for the modification of fully authorized vaccines to substitute only the $\mathrm{S}$ sequence for the variant $\mathrm{S}$ sequence.

\section{Conclusion and Perspective}

By conducting immunological analysis of the working mechanisms of EUL vaccines, we can determine the possible causes of issues related to the vaccinations and ascertain why the adenovirus-vectored vaccines are potentially more problematic than the mRNA-LNP vaccines (dependent on the administered dose). Clinical trials for optimally reducing the number of vaccine adenovirus particles in one dose would be beneficial, especially in relation to the ChAdOx $1 \mathrm{nCoV}-19$ vaccine. It is also reasonable to suggest that, despite breakthrough infection of a VOC being possible after vaccination in terms of $\mathrm{nAb}$ response, the functioning $\mathrm{T}$-cell responses would enable those infected to recover rapidly similar to in asymptomatic or mild cases of naïve infection. Because the $\mathrm{T}$-cell responses appear to be more critical than the $\mathrm{nAb}$ responses against SARS-CoV-2, VOCs might result from the virus adapting to its human host and thereby producing enhanced replication and transmission competence with coincidental $\mathrm{nAb}$ evasion. It might still be possible to eradicate SARS-CoV-2 using global vaccination efforts and necessary social distancing; however, the question remains: can our vaccination drive be sufficiently rapid and globally conducted?

\section{Acknowledgements}

This study was supported by a grant from the National Research Foundation of Korea (NRF) funded by the Ministry of Science and ICT, Republic of Korea (grant No. NRF2017M3A9E4061995).

\section{Conflict of Interest}

The authors declare no competing interests. 


\section{References}

Ackermann, M., Verleden, S.E., Kuehnel, M., Haverich, A., Welte, T., Laenger, F., Vanstapel, A., Werlein, C., Stark, H., Tzankov, A., et al. 2020. Pulmonary vascular endothelialitis, thrombosis, and angiogenesis in Covid-19. N. Engl. J. Med. 383, 120-128.

Aid, M., Busman-Sahay, K., Vidal, S.J., Maliga, Z., Bondoc, S., Starke, C., Terry, M., Jacobson, C.A., Wrijil, L., Ducat, S., et al. 2020. Vascular disease and thrombosis in SARS-CoV-2-infected rhesus macaques. Cell 183, 1354-1366.

Al-Samkari, H., Karp Leaf, R.S., Dzik, W.H., Carlson, J.C.T., Fogerty, A.E., Waheed, A., Goodarzi, K., Bendapudi, P.K., Bornikova, L., Gupta, S., et al. 2020. COVID-19 and coagulation: bleeding and thrombotic manifestations of SARS-CoV-2 infection. Blood 136, 489-500.

Almuqrin, A., Davidson, A.D., Williamson, M.K., Lewis, P.A., Heesom, K.J., Morris, S., Gilbert, S.C., and Matthews, D.A. 2021. SARSCoV-2 vaccine ChAdOx1 nCoV-19 infection of human cell lines reveals low levels of viral backbone gene transcription alongside very high levels of SARS-CoV-2 S glycoprotein gene transcription. Genome Med. 13, 43.

Alrubayyi, A. and Peppa, D. 2021. Seeing SARS-CoV-2 variants through the eyes of T cells. Nat. Rev. Immunol. 21, 274.

Angeli, F., Spanevello, A., Reboldi, G., Visca, D., and Verdecchia, P. 2021. SARS-CoV-2 vaccines: lights and shadows. Eur. J. Intern. Med. 88, 1-8.

Bae, J.Y., Kim, J.I., Park, M.S., Lee, G.E., Park, H., Song, K.J., and Park, M.S. 2021. The immune correlates of Orthohantavirus vaccine. Vaccines 9, 518.

Baumgarth, N., Nikolich-Žugich, J., Lee, F.E., and Bhattacharya, D. 2020. Antibody responses to SARS-CoV-2: let's stick to known knowns. J. Immunol. 205, 2342-2350.

Bellmunt-Montoya, S., Riera, C., Gil, D., Rodríguez, M., GarcíaReyes, M., Martínez-Carnovale, L., Marrero, C., Gil, M., RuizRodríguez, J.C., Ferrer, R., et al. 2021. COVID-19 infection in critically ill patients carries a high risk of venous thrombo-embolism. Eur. J. Vasc. Endovasc. Surg. 61, 628-634.

Braun, J., Loyal, L., Frentsch, M., Wendisch, D., Georg, P., Kurth, F., Hippenstiel, S., Dingeldey, M., Kruse, B., Fauchere, F., et al. 2020. SARS-CoV-2-reactive T cells in healthy donors and patients with COVID-19. Nature 587, 270-274.

Buschmann, M.D., Carrasco, M.J., Alishetty, S., Paige, M., Alameh, M.G., and Weissman, D. 2021. Nanomaterial delivery systems for mRNA vaccines. Vaccines 9, 65 .

Calabretta, E., Moraleda, J.M., Iacobelli, M., Jara, R., Vlodavsky, I., O'Gorman, P., Pagliuca, A., Mo, C., Baron, R.M., Aghemo, A., et al. 2021. COVID-19-induced endotheliitis: emerging evidence and possible therapeutic strategies. Br. J. Haematol. 193, 43-51.

Campana, P., Parisi, V., Leosco, D., Bencivenga, D., Della Ragione, F., and Borriello, A. 2020. Dendritic cells and SARS-CoV-2 infection: still an unclarified connection. Cells 9, 2046.

Cardone, J., Le Friec, G., and Kemper, C. 2011. CD46 in innate and adaptive immunity: an update. Clin. Exp. Immunol. 164, 301-311.

Channappanavar, R., Fett, C., Zhao, J., Meyerholz, D.K., and Perlman, S. 2014. Virus-specific memory CD8 T cells provide substantial protection from lethal severe acute respiratory syndrome coronavirus infection. J. Virol. 88, 11034-11044.

Cines, D.B. and Bussel, J.B. 2021. SARS-CoV-2 vaccine-induced immune thrombotic thrombocytopenia. N. Engl. J. Med. 384, 2254-2256.

Colbert, J.D., Cruz, F.M., and Rock, K.L. 2020. Cross-presentation of exogenous antigens on MHC I molecules. Curr. Opin. Immunol. 64, 1-8.

Connolly-Andersen, A.M., Sundberg, E., Ahlm, C., Hultdin, J., Baudin, M., Larsson, J., Dunne, E., Kenny, D., Lindahl, T.L., Ramström, S., et al. 2015. Increased thrombopoiesis and platelet acti- vation in hantavirus-infected patients. J. Infect. Dis. 212, 10611069.

Coronaviridae Study Group of the International Committee on Taxonomy of Viruses. 2020. The species Severe acute respiratory syndrome-related coronavirus: classifying 2019-nCoV and naming it SARS-CoV-2. Nat. Microbiol. 5, 536-544.

Dan, J.M., Mateus, J., Kato, Y., Hastie, K.M., Yu, E.D., Faliti, C.E., Grifoni, A., Ramirez, S.I., Haupt, S., Frazier, A., et al. 2021. Immunological memory to SARS-CoV-2 assessed for up to 8 months after infection. Science 371, eabf4063.

Del Val, M., Antón, L.C., Ramos, M., Muñoz-Abad, V., and CamposSánchez, E. 2020. Endogenous TAP-independent MHC-I antigen presentation: not just the ER lumen. Curr. Opin. Immunol. 64, 9-14.

Du, L., He, Y., Zhou, Y., Liu, S., Zheng, B.J., and Jiang, S. 2009. The spike protein of SARS-CoV-a target for vaccine and therapeutic development. Nat. Rev. Microbiol. 7, 226-236.

Ewer, K.J., Barrett, J.R., Belij-Rammerstorfer, S., Sharpe, H., Makinson, R., Morter, R., Flaxman, A., Wright, D., Bellamy, D., Bittaye, M., et al. 2021. T cell and antibody responses induced by a single dose of ChAdOx1 nCoV-19 (AZD1222) vaccine in a phase $1 / 2$ clinical trial. Nat. Med. 27, 270-278.

Farkas, A. and Kemény, L. 2011. Interferon- $\alpha$ in the generation of monocyte-derived dendritic cells: recent advances and implications for dermatology. Br. J. Dermatol. 165, 247-254.

Favaloro, E.J., Henry, B.M., and Lippi, G. 2021. The complicated relationships of heparin-induced thrombocytopenia and platelet factor 4 antibodies with COVID-19. Int. J. Lab. Hematol. 43, 547558.

Folegatti, P.M., Ewer, K.J., Aley, P.K., Angus, B., Becker, S., BelijRammerstorfer, S., Bellamy, D., Bibi, S., Bittaye, M., Clutterbuck, E.A., et al. 2020. Safety and immunogenicity of the ChAdOx1 $\mathrm{nCoV}-19$ vaccine against SARS-CoV-2: a preliminary report of a phase $1 / 2$, single-blind, randomised controlled trial. Lancet 396, 467-478.

Fraiman, P., Godeiro Junior, C., Moro, E., Cavallieri, F., and Zedde, M. 2020. COVID-19 and cerebrovascular diseases: a systematic review and perspectives for stroke management. Front. Neurol. 11, 574694 .

Frenz, T., Grabski, E., Durán, V., Hozsa, C., Stępczyńska, A., Furch, M., Gieseler, R.K., and Kalinke, U. 2015. Antigen presenting cellselective drug delivery by glycan-decorated nanocarriers. Eur. J. Pharm. Biopharm. 95, 13-17.

Gajewski, T.F. and Fitch, F.W. 1988. Anti-proliferative effect of IFN- $\gamma$ in immune regulation. I. IFN- $\gamma$ inhibits the proliferation of Th2 but not Th1 murine helper T lymphocyte clones. J. Immunol. 140, $4245-4252$.

Garcia-Beltran, W.F., Lam, E.C., St. Denis, K., Nitido, A.D., Garcia, Z.H., Hauser, B.M., Feldman, J., Pavlovic, M.N., Gregory, D.J., Poznansky, M.C., et al. 2021. Multiple SARS-CoV-2 variants escape neutralization by vaccine-induced humoral immunity. Cell 184, 2372-2383.

Gebre, M.S., Brito, L.A., Tostanoski, L.H., Edwards, D.K., Carfi, A., and Barouch, D.H. 2021. Novel approaches for vaccine development. Cell 184, 1589-1603.

Golob, J.L., Lugogo, N., Lauring, A.S., and Lok, A.S. 2021. SARSCoV-2 vaccines: a triumph of science and collaboration. JCI Insight 6, e149187.

Goshua, G., Pine, A.B., Meizlish, M.L., Chang, C.H., Zhang, H., Bahel, P., Baluha, A., Bar, N., Bona, R.D., Burns, A.J., et al. 2020. Endotheliopathy in COVID-19-associated coagulopathy: evidence from a single-centre, cross-sectional study. Lancet Haematol. 7, e575-e582.

Greinacher, A., Thiele, T., Warkentin, T.E., Weisser, K., Kyrle, P.A., and Eichinger, S. 2021. Thrombotic thrombocytopenia after ChAdOx1 nCov-19 vaccination. N. Engl. J. Med. 384, 2092-2101.

Hamming, I., Timens, W., Bulthuis, M.L.C., Lely, A.T., Navis, G., and 
van Goor, H. 2004. Tissue distribution of ACE2 protein, the functional receptor for SARS coronavirus. A first step in understanding SARS pathogenesis. J. Pathol. 203, 631-637.

Hanley, B., Naresh, K.N., Roufosse, C., Nicholson, A.G., Weir, J., Cooke, G.S., Thursz, M., Manousou, P., Corbett, R., Goldin, R. et al. 2020. Histopathological findings and viral tropism in UK patients with severe fatal COVID-19: a post-mortem study. Lancet Microbe 1, e245-e253.

Heinz, F.X. and Stiasny, K. 2021. Profiles of current COVID-19 vaccines. Wien. Klin. Wochenschr. 133, 271-283.

Hoffmann, M., Kleine-Weber, H., Schroeder, S., Krüger, N., Herrler, T., Erichsen, S., Schiergens, T.S., Herrler, G., Wu, N.H., Nitsche, A., et al. 2020. SARS-CoV-2 cell entry depends on ACE2 and TMPRSS2 and is blocked by a clinically proven protease inhibitor. Cell 181, 271-280.

Hou, X., Zaks, T., Langer, R., and Dong, Y. 2021. Lipid nanoparticles for mRNA delivery. Nat. Rev. Mater. 6, 1078-1094.

Jackson, L.A., Anderson, E.J., Rouphael, N.G., Roberts, P.C., Makhene, M., Coler, R.N., McCullough, M.P., Chappell, J.D., Denison, M.R., Stevens, L.J., et al. 2020. An mRNA vaccine against SARSCoV-2 -preliminary report. N. Engl. J. Med. 383, 1920-1931.

Jaume, M., Yip, M.S., Cheung, C.Y., Leung, H.L., Li, P.H., Kien, F., Dutry, I., Callendret, B., Escriou, N., Altmeyer, R., et al. 2011. Anti-severe acute respiratory syndrome coronavirus spike antibodies trigger infection of human immune cells via a $\mathrm{pH}$ - and cysteine protease-independent $\mathrm{Fc} \gamma \mathrm{R}$ pathway. J. Virol. 85, 1058210597.

Kantarcioglu, B., Iqbal, O., Walenga, J.M., Lewis, B., Lewis, J., Carter, C.A., Singh, M., Lievano, F., Tafur, A., Ramacciotti, E., et al. 2021. An update on the pathogenesis of COVID-19 and the reportedly rare thrombotic events following vaccination. Clin. Appl. Thromb. Hemost. 27. doi: $10.1177 / 10760296211021498$.

Kawai, T. and Akira, S. 2008. Toll-like receptor and RIG-I-like receptor signaling. Ann. N. Y. Acad. Sci. 1143, 1-20.

Kim, C., Ryu, D.K., Lee, J., Kim, Y.I., Seo, J.M., Kim, Y.G., Jeong, J.H., Kim, M., Kim, J.I., Kim, P., et al. 2021. A therapeutic neutralizing antibody targeting receptor binding domain of SARS-CoV-2 spike protein. Nat. Commun. 12, 288.

Krammer, F. 2020. SARS-CoV-2 vaccines in development. Nature 586, 516-527.

Krammer, F. 2021. A correlate of protection for SARS-CoV-2 vaccines is urgently needed. Nat. Med. 27, 1147-1148.

Larochelle, N., Deol, J.R., Srivastava, V., Allen, C., Mizuguchi, H., Karpati, G., Holland, P.C., and Nalbantoglu, J. 2008. Downregulation of CD46 during muscle differentiation: implications for gene transfer to human skeletal muscle using group B adenoviruses. Hum. Gene Ther. 19, 133-142.

Le Bert, N., Tan, A.T., Kunasegaran, K., Tham, C.Y.L., Hafezi, M., Chia, A., Chng, M.H.Y., Lin, M., Tan, N., Linster, M., et al. 2020. SARS-CoV-2-specific T cell immunity in cases of COVID-19 and SARS, and uninfected controls. Nature 584, 457-462.

Leblanc, J.F., Germain, M., Delage, G., O'Brien, S., Drews, S.J., and Lewin, A. 2020. Risk of transmission of severe acute respiratory syndrome coronavirus 2 by transfusion: a literature review. Transfusion 60, 3046-3054.

Leentjens, J., van Haaps, T.F., Wessels, P.F., Schutgens, R.E.G., and Middeldorp, S. 2021. COVID-19-associated coagulopathy and antithrombotic agents-lessons after 1 year. Lancet Haematol. 8, e524-e533.

Leifer, C.A. and Medvedev, A.E. 2016. Molecular mechanisms of regulation of Toll-like receptor signaling. J. Leukoc. Biol. 100 , 927-941.

Li, D., Edwards, R.J., Manne, K., Martinez, D.R., Schäfer, A., Alam, S.M., Wiehe, K., Lu, X., Parks, R., Sutherland, L.L., et al. 2021a. In vitro and in vivo functions of SARS-CoV-2 infection-enhancing and neutralizing antibodies. Cell 184, 4203-4219.

Li, W., Moore, M.J., Vasilieva, N., Sui, J., Wong, S.K., Berne, M.A.,
Somasundaran, M., Sullivan, J.L., Luzuriaga, K., Greenough, T.C., et al. 2003. Angiotensin-converting enzyme 2 is a functional receptor for the SARS coronavirus. Nature 426, 450-454.

Li, H., Rhee, E.G., Masek-Hammerman, K., Teigler, J.E., Abbink, P., and Barouch, D.H. 2012. Adenovirus serotype 26 utilizes CD46 as a primary cellular receptor and only transiently activates $\mathrm{T}$ lymphocytes following vaccination of rhesus monkeys. J. Virol. 86, 10862-10865.

Li, Y., Schneider, A.M., Mehta, A., Sade-Feldman, M., Kays, K.R., Gentili, M., Charland, N.C., Gonye, A.L.K., Gushterova, I., Khanna, H.K., et al. 2021b. SARS-CoV-2 viremia is associated with distinct proteomic pathways and predicts COVID-19 outcomes. J. Clin. Invest. 131, e148635.

Li, P., Spolski, R., Liao, W., and Leonard, W.J. 2014. Complex interactions of transcription factors in mediating cytokine biology in T cells. Immunol. Rev. 261, 141-156.

Li, C.K., Wu, H., Yan, H., Ma, S., Wang, L., Zhang, M., Tang, X., Temperton, N.J., Weiss, R.A., Brenchley, J.M., et al. 2008. T cell responses to whole SARS coronavirus in humans. J. Immunol. 181, 5490-5500.

Liao, W., Lin, J.X., and Leonard, W.J. 2013. Interleukin-2 at the crossroads of effector responses, tolerance, and immunotherapy. Immunity 38, 13-25.

Lipsitch, M., Grad, Y.H., Sette, A., and Crotty, S. 2020. Cross-reactive memory T cells and herd immunity to SARS-CoV-2. Nat. Rev. Immunol. 20, 709-713.

Liu, Q., Zhou, S., Fan, C., Huang, W., Li, Q., Liu, S., Wu, X., Li, B., and Wang, Y. 2017. Biodistribution and residence time of adenovector serotype 5 in normal and immunodeficient mice and rats detected with bioluminescent imaging. Sci. Rep. 7, 3597.

Lu, R., Zhao, X., Li, J., Niu, P., Yang, B., Wu, H., Wang, W., Song, H., Huang, B., Zhu, N., et al. 2020. Genomic characterisation and epidemiology of 2019 novel coronavirus: implications for virus origins and receptor binding. Lancet 395, 565-574.

Lumley, S.F., O'Donnell, D., Stoesser, N.E., Matthews, P.C., Howarth, A., Hatch, S.B., Marsden, B.D., Cox, S., James, T., Warren, F., et al. 2021. Antibody status and incidence of SARS-CoV-2 infection in health care workers. N. Engl. J. Med. 384, 533-540.

MacNeil, J.R., Su, J.R., Broder, K.R., Guh, A.Y., Gargano, J.W., Wallace, M., Hadler, S.C., Scobie, H.M., Blain, A.E., Moulia, D., et al. 2021. Updated Recommendations from the Advisory Committee on Immunization Practices for Use of the Janssen (Johnson \& Johnson) COVID-19 Vaccine After Reports of Thrombosis with Thrombocytopenia Syndrome Among Vaccine Recipients - United States, April 2021. MMWR Morb. Mortal. Wkly. Rep. 70, 651-656.

Masters, P.S. and Perlman, S. 2013. Coronaviridae. In Knipe, D.M. and Howley, P. (eds.), Fields Virology, 6th edn., pp. 825-858. Lippincott Williams \& Wilkins, Philadelphia, USA.

Mateus, J., Grifoni, A., Tarke, A., Sidney, J., Ramirez, S.I., Dan, J.M., Burger, Z.C., Rawlings, S.A., Smith, D.M., Phillips, E., et al. 2020. Selective and cross-reactive SARS-CoV-2 T cell epitopes in unexposed humans. Science 370, 89-94.

McGonagle, D., De Marco, G., and Bridgewood, C. 2021. Mechanisms of immunothrombosis in vaccine-induced thrombotic thrombocytopenia (VITT) compared to natural SARS-CoV-2 infection. J. Autoimmun. 121, 102662.

Medema, J.P., Schuurhuis, D.H., Rea, D., van Tongeren, J., de Jong, J., Bres, S.A., Laban, S., Toes, R.E., Toebes, M., Schumacher, T.N., et al. 2001. Expression of the serpin serine protease inhibitor 6 protects dendritic cells from cytotoxic T lymphocyte-induced apoptosis: differential modulation by $\mathrm{T}$ helper type 1 and type 2 cells. J. Exp. Med. 194, 657-667.

Mizuguchi, H. and Hayakawa, T. 2004. Targeted adenovirus vectors. Hum. Gene Ther. 15, 1034-1044.

Morris, S.J., Sebastian, S., Spencer, A.J., and Gilbert, S.C. 2016. Simian adenoviruses as vaccine vectors. Future Virol. 11, 649-659. 
Mulligan, M.J., Lyke, K.E., Kitchin, N., Absalon, J., Gurtman, A., Lockhart, S., Neuzil, K., Raabe, V., Bailey, R., Swanson, K.A., et al. 2020. Phase I/II study of COVID-19 RNA vaccine BNT162b1 in adults. Nature 586, 589-593.

Nair-Gupta, P., Baccarini, A., Tung, N., Seyffer, F., Florey, O., Huang, Y., Banerjee, M., Overholtzer, M., Roche, P.A., Tampé, R., et al. 2014. TLR signals induce phagosomal MHC-I delivery from the endosomal recycling compartment to allow cross-presentation. Cell 158, 506-521.

Ng, O.W., Chia, A., Tan, A.T., Jadi, R.S., Leong, H.N., Bertoletti, A., and Tan, Y.J. 2016. Memory T cell responses targeting the SARS coronavirus persist up to 11 years post-infection. Vaccine 34, 2008-2014.

Noack, D., Goeijenbier, M., Reusken, C., Koopmans, M.P.G., and Rockx, B.H.G. 2020. Orthohantavirus pathogenesis and cell tropism. Front. Cell. Infect. Microbiol. 10, 399.

O'Shea, J.J. and Paul, W.E. 2010. Mechanisms underlying lineage commitment and plasticity of helper $\mathrm{CD}^{+} \mathrm{T}$ cells. Science 327, 1098-1102.

O'Sullivan, J.M., Gonagle, D.M., Ward, S.E., Preston, R.J.S., and O'Donnell, J.S. 2020. Endothelial cells orchestrate COVID-19 coagulopathy. Lancet Haematol. 7, e553-e555.

Oh, H.J., Chia, A., Chang, C.X.L., Leong, H.N., Ling, K.L., Grotenbreg, G.M., Gehring, A.J., Tan, Y.J., and Bertoletti, A. 2011. Engineering $\mathrm{T}$ cells specific for a dominant severe acute respiratory syndrome coronavirus CD8 T cell epitope. J. Virol. 85, 1046410471.

Østergaard, S.D., Schmidt, M., Horváth-Puhó, E., Thomsen, R.W., and Sørensen, H.T. 2021. Thromboembolism and the OxfordAstraZeneca COVID-19 vaccine: side-effect or coincidence? Lancet 397, 1441-1443.

Oxley, T.J., Mocco, J., Majidi, S., Kellner, C.P., Shoirah, H., Singh, I.P., De Leacy, R.A., Shigematsu, T., Ladner, T.R., Yaeger, K.A., et al. 2020. Large-vessel stroke as a presenting feature of Covid19 in the young. N. Engl. J. Med. 382, e60.

Pardi, N., Hogan, M.J., Porter, F.W., and Weissman, D. 2018. mRNA vaccines - a new era in vaccinology. Nat. Rev. Drug. Discov. 17, 261-279.

Pardi, N., Tuyishime, S., Muramatsu, H., Kariko, K., Mui, B.L., Tam, Y.K., Madden, T.D., Hope, M.J., and Weissman, D. 2015. Expression kinetics of nucleoside-modified mRNA delivered in lipid nanoparticles to mice by various routes. J. Control. Release 217, 345-351.

Pillon, N.J., Bilan, P.J., Fink, L.N., and Klip, A. 2013. Cross-talk between skeletal muscle and immune cells: muscle-derived mediators and metabolic implications. Am. J. Physiol. Endocrinol. Metab. 304, E453-E465.

Pottegård, A., Lund, L.C., Karlstad, Ø., Dahl, J., Andersen, M., Hallas, J., Lidegaard, Ø., Tapia, G., Gulseth, H.L., Ruiz, P.L., et al. 2021. Arterial events, venous thromboembolism, thrombocytopenia, and bleeding after vaccination with Oxford-AstraZeneca ChAdOx1-S in Denmark and Norway: population based cohort study. BMJ 373, n1114.

Roelvink, P.W., Lizonova, A., Lee, J.G.M., Li, Y., Bergelson, J.M., Finberg, R.W., Brough, D.E., Kovesdi, I., and Wickham, T.J. 1998. The coxsackievirus-adenovirus receptor protein can function as a cellular attachment protein for adenovirus serotypes from subgroups A, C, D, E, and F. J. Virol. 72, 7909-7915.

Ronchese, F. and Hermans, I.F. 2001. Killing of dendritic cells: a life cut short or a purposeful death? J. Exp. Med. 194, F23-F26.

Rydyznski Moderbacher, C., Ramirez, S.I., Dan, J.M., Grifoni, A., Hastie, K.M., Weiskopf, D., Belanger, S., Abbott, R.K., Kim, C., Choi, J., et al. 2020. Antigen-specific adaptive immunity to SARSCoV-2 in acute COVID-19 and associations with age and disease severity. Cell 183, 996-1012.

Sadoff, J., Le Gars, M., Shukarev, G., Heerwegh, D., Truyers, C., de Groot, A.M., Stoop, J., Tete, S., Van Damme, W., Leroux-Roels,
I., et al. 2021. Interim results of a phase 1-2a trial of Ad26.COV2.S Covid-19 vaccine. N. Engl. J. Med. 384, 1824-1835.

Sagar, M., Reifler, K., Rossi, M., Miller, N.S., Sinha, P., White, L.F., and Mizgerd, J.P. 2021. Recent endemic coronavirus infection is associated with less-severe COVID-19. J. Clin. Invest. 131, e143380.

Sahni, S.K. 2007. Endothelial cell infection and hemostasis. Thromb. Res. 119, 531-549.

Santiesteban-Lores, L.E., Amamura, T.A., da Silva, T.F., Midon, L.M., Carneiro, M.C., Isaac, L., and Bavia, L. 2021. A double edged-sword - the complement system during SARS-CoV-2 infection. Life Sci. $272,119245$.

Schmedes, C.M., Grover, S.P., Hisada, Y.M., Goeijenbier, M., Hultdin, J., Nilsson, S., Thunberg, T., Ahlm, C., Mackman, N., and Fors Connolly, A.M. 2020. Circulating extracellular vesicle tissue factor activity during orthohantavirus infection is associated with intravascular coagulation. J. Infect. Dis. 222, 1392-1399.

Schmidt, T., Klemis, V., Schub, D., Mihm, J., Hielscher, F., Marx, S., Abu-Omar, A., Ziegler, L., Guckelmus, C., Urschel, R., et al. 2021. Immunogenicity and reactogenicity of heterologous ChAdOx1 nCoV-19/mRNA vaccination. Nat. Med. 27, 1530-1535.

Sengupta, D., Graham, M., Liu, X., and Cresswell, P. 2019. Proteasomal degradation within endocytic organelles mediates antigen cross-presentation. EMBO J. 38, e99266.

Shang, J., Ye, G., Shi, K., Wan, Y., Luo, C., Aihara, H., Geng, Q., Auerbach, A., and Li, F. 2020. Structural basis of receptor recognition by SARS-CoV-2. Nature 581, 221-224.

Shay, D.K., Gee, J., Su, J.R., Myers, T.R., Marquez, P., Liu, R., Zhang, B., Licata, C., Clark, T.A., and Shimabukuro, T.T. 2021. Safety monitoring of the Janssen (Johnson \& Johnson) COVID-19 vaccine - United States, March-April 2021. MMWR Morb. Mortal. Wkly. Rep. 70, 680-684.

Siddiqi, H.K. and Mehra, M.R. 2020. COVID-19 illness in native and immunosuppressed states: a clinical-therapeutic staging proposal. J. Heart Lung Transplant. 39, 405-407.

Stephenson, K.E., Le Gars, M., Sadoff, J., de Groot, A.M., Heerwegh, D., Truyers, C., Atyeo, C., Loos, C., Chandrashekar, A., McMahan, K., et al. 2021. Immunogenicity of the Ad26.COV2.S vaccine for COVID-19. JAMA 325, 1535-1544.

Sungnak, W., Huang, N., Bécavin, C., Berg, M., Queen, R., Litvinukova, M., Talavera-López, C., Maatz, H., Reichart, D., Sampaziotis, F., et al. 2020. SARS-CoV-2 entry factors are highly expressed in nasal epithelial cells together with innate immune genes. Nat. Med. 26, 681-687.

Tan, A.T., Linster, M., Tan, C.W., Le Bert, N., Chia, W.N., Kunasegaran, K., Zhuang, Y., Tham, C.Y.L., Chia, A., Smith, G.J.D., et al. 2021. Early induction of functional SARS-CoV-2-specific T cells associates with rapid viral clearance and mild disease in COVID19 patients. Cell Rep. 34, 108728.

Tang, F., Quan, Y., Xin, Z.T., Wrammert, J., Ma, M.J., Lv, H., Wang, T.B., Yang, H., Richardus, J.H., Liu, W., et al. 2011. Lack of peripheral memory B cell responses in recovered patients with severe acute respiratory syndrome: a six-year follow-up study. $J$. Immunol. 186, 7264-7268.

Tarke, A., Sidney, J., Methot, N., Yu, E.D., Zhang, Y., Dan, J.M., Goodwin, B., Rubiro, P., Sutherland, A., Wang, E., et al. 2021. Impact of SARS-CoV-2 variants on the total $\mathrm{CD}^{+}$and $\mathrm{CD}^{+} \mathrm{T}$ cell reactivity in infected or vaccinated individuals. Cell Rep. Med. 2, 100355.

Tegally, H., Wilkinson, E., Giovanetti, M., Iranzadeh, A., Fonseca, V., Giandhari, J., Doolabh, D., Pillay, S., San, E.J., Msomi, N., et al. 2021. Detection of a SARS-CoV-2 variant of concern in South Africa. Nature 592, 438-443.

Teijaro, J.R. and Farber, D.L. 2021. COVID-19 vaccines: modes of immune activation and future challenges. Nat. Rev. Immunol. 21, 195-197.

Théry, C., Ostrowski, M., and Segura, E. 2009. Membrane vesicles as conveyors of immune responses. Nat. Rev. Immunol. 9, 581-593. 
Tseng, C.T., Sbrana, E., Iwata-Yoshikawa, N., Newman, P.C., Garron, T., Atmar, R.L., Peters, C.J., and Couch, R.B. 2012. Immunization with SARS coronavirus vaccines leads to pulmonary immunopathology on challenge with the SARS virus. PLoS ONE 7, e35421.

Valliyott, L., Dungdung, R., and Pilankatta, R. 2020. Semi-quantification of antibody-dependent enhancement (ADE) in the uptake of Adenovirus serotype 5 into THP-1 cells. Anal. Biochem. 591, 113568.

Varga, Z., Flammer, A.J., Steiger, P., Haberecker, M., Andermatt, R., Zinkernagel, A.S., Mehra, M.R., Schuepbach, R.A., Ruschitzka F., and Moch, H. 2020. Endothelial cell infection and endotheliitis in COVID-19. Lancet 395, 1417-1418.

Vaz de Paula, C.B., de Azevedo, M.L.V., Nagashima, S., Martins, A.P.C., Malaquias, M.A.S., Miggiolaro, A.F.R., da Silva Motta Júnior, J., Avelino, G., do Carmo, L.A.P., Carstens, L.B., et al. 2020. IL-4/IL-13 remodeling pathway of COVID-19 lung injury. Sci. Rep. 10, 18689.

Wajnberg, A., Amanat, F., Firpo, A., Altman, D.R., Bailey, M.J., Mansour, M., McMahon, M., Meade, P., Mendu, D.R., Muellers, K., et al. 2020a. Robust neutralizing antibodies to SARS-CoV-2 infection persist for months. Science 370, 1227-1230.

Wajnberg, A., Mansour, M., Leven, E., Bouvier, N.M., Patel, G., Firpo-Betancourt, A., Mendu, R., Jhang, J., Arinsburg, S., Gitman, M., et al. 2020b. Humoral response and PCR positivity in patients with COVID-19 in the New York City region, USA: an observational study. Lancet Microbe 1, E283-E289.

Wall, E.C., Wu, M., Harvey, R., Kelly, G., Warchal, S., Sawyer, C., Daniels, R., Adams, L., Hobson, P., Hatipoglu, E., et al. $2021 \mathrm{a}$. AZD1222-induced neutralising antibody activity against SARSCoV-2 Delta VOC. Lancet 398, 207-209.

Wall, E.C., Wu, M., Harvey, R., Kelly, G., Warchal, S., Sawyer, C., Daniels, R., Hobson, P., Hatipoglu, E., Ngai, Y., et al. 2021b. Neutralising antibody activity against SARS-CoV-2 VOCs B.1.617.2 and B.1.351 by BNT162b2 vaccination. Lancet 397, 2331-2333.

Walsh, E.E., Frenck, R.W.Jr, Falsey, A.R., Kitchin, N., Absalon, J., Gurtman, A., Lockhart, S., Neuzil, K., Mulligan, M.J., Bailey, R., et al. 2020. Safety and immunogenicity of two rna-based Covid-19 vaccine candidates. N. Engl. J. Med. 383, 2439-2450.

Wan, Y., Shang, J., Graham, R., Baric, R.S., and Li, F. 2020a. Receptor recognition by the novel coronavirus from Wuhan: an analysis based on decade-long structural studies of SARS coronavirus. J. Virol. 94, e00127-20.

Wan, Y., Shang, J., Sun, S., Tai, W., Chen, J., Geng, Q., He, L., Chen,
Y., Wu, J., Shi, Z., et al. 2020b. Molecular mechanism for antibody-dependent enhancement of coronavirus entry. J. Virol. $\mathbf{9 4}$ e02015-19.

Wang, H., Zhang, Y., Huang, B., Deng, W., Quan, Y., Wang, W., Xu, W., Zhao, Y., Li, N., Zhang, J., et al. 2020. Development of an inactivated vaccine candidate, BBIBP-CorV, with potent protection against SARS-CoV-2. Cell 182, 713-721.

Weinreich, D.M., Sivapalasingam, S., Norton, T., Ali, S., Gao, H., Bhore, R., Musser, B.J., Soo, Y., Rofail, D., Im, J., et al. 2021. REGNCOV2, a neutralizing antibody cocktail, in outpatients with Covid19. N. Engl. J. Med. 384, 238-251.

Wold, W.S.M. and Ison, M.G. 2013. Adenoviruses. In Knipe, D.M. and Howley, P. (eds.), Fields Virology, 6th edn., pp. 1732-1767. Lippincott Williams \& Wilkins, Philadelphia, USA.

Wong, D.W.L., Klinkhammer, B.M., Djudjaj, S., Villwock, S., Timm, M.C., Buhl, E.M., Wucherpfennig, S., Cacchi, C., Braunschweig, T., Knüchel-Clarke, R., et al. 2021. Multisystemic cellular tropism of SARS-CoV-2 in autopsies of COVID-19 patients. Cells 10, 1900.

Wu, F., Zhao, S., Yu, B., Chen, Y.M., Wang, W., Song, Z.G., Hu, Y., Tao, Z.W., Tian, J.H., Pei, Y.Y., et al. 2020. A new coronavirus associated with human respiratory disease in China. Nature 579, 265-269.

Yang, L., Peng, H., Zhu, Z., Li, G., Huang, Z., Zhao, Z., Koup, R.A. Bailer, R.T., and Wu, C. 2007. Persistent memory CD4 $4^{+}$and $\mathrm{CD} 8^{+}$ $\mathrm{T}$-cell responses in recovered severe acute respiratory syndrome (SARS) patients to SARS coronavirus M antigen. J. Gen. Virol. 88, 2740-2748.

Zhang, Y., Zeng, G., Pan, H., Li, C., Hu, Y., Chu, K., Han, W., Chen, Z., Tang, R., Yin, W., et al. 2021. Safety, tolerability, and immunogenicity of an inactivated SARS-CoV-2 vaccine in healthy adults aged 18-59 years: a randomised, double-blind, placebo-controlled, phase 1/2 clinical trial. Lancet Infect. Dis. 21, 181-192.

Zheng, J., Wang, Y., Li, K., Meyerholz, D.K., Allamargot, C., and Perlman, S. 2021. Severe acute respiratory syndrome coronavirus 2 -induced immune activation and death of monocyte-derived human macrophages and dendritic cells. J. Infect. Dis. 223, 785795.

Zhu, N., Zhang, D., Wang, W., Li, X., Yang, B., Song, J., Zhao, X., Huang, B., Shi, W., Lu, R., et al. 2020. A Novel coronavirus from patients with pneumonia in China, 2019. N. Engl. J. Med. 382, 727-733. 